\title{
Preparation of Hybridomas Producing Monoclonal Antibodies against Aflatoxin B1 as a Tool to Control Hepatocellular Carcinoma
}

\author{
Manal M. E. Ahmed ${ }^{1,{ }^{*}}$, Rafik Soliman², Jakeen Eljakee ${ }^{2}$, \\ Ahmed El-Sanousi ${ }^{3}$, Haitham Amer ${ }^{3}$, Ibrahim El-Sabagh ${ }^{3}$, \\ Rashika El-Redii ${ }^{4}$, Hateem Talima ${ }^{4}$, Walid Nazmy ${ }^{5}$ \\ ${ }^{1}$ Pharmacology Department, Medical Research Division, National Research Centre \\ ${ }^{2}$ Microbiology Department, Faculty of Veterinary Medicine, Cairo University \\ ${ }^{3}$ Virology Department, Faculty of Veterinary Medicine, Cairo University \\ ${ }^{4}$ Immunology Department, Faculty of Sciences, Cairo University \\ ${ }^{5}$ The holding company of vaccines and biological products \\ "thinktankteam2014@gmail.com
}

Keywords: mycotoxins, aflatoxins, aflatoxin B1, hybridoma, monoclonal antibodies, cell fusion.

\begin{abstract}
Hybridomas that secreted antibodies against aflatoxin B1 for multiple uses were prepared using a unique immunization schedule. Aflatoxin B1-BSA conjugate was used for immunization of $\mathrm{Balb} / \mathrm{c}$ mice. Spleen cells were harvested from the hyper immunized mice to be fused with myeloma cell line (P3NS1) using polyethylene glycol 3000, 50\% concentration as a fusogenic agent. The produced hybridomas were selected using HAT selective medium that was replaced by complete HT medium. From the $10^{\text {th }}$ day after fusion, wells that contain colonies of hybridomas covering $30 \%$ or greater of the wells surface were screened for production of monoclonal antibodies against aflatoxin B1 using ELISA. 21 hybridomas were found to be reactive to aflatoxin B1. All were found to belong to IgG2a isotype except one was found to belong to IgM isotype. The prepared monoclonal antibodies and their application to immunoassays represent a useful and rapid quantitative measurement with high affinity and low detection limits in order to purify environmentally occurring levels of this carcinogen specially in areas at high risk for liver cancer.
\end{abstract}

\section{Introduction}

Aflatoxins are a group of carcinogenic, mutagenic and teratogenic secondary metabolites of Aspergillus flavus and Aspergillus parasiticus, which are ubiquitous in food commodities and live stock feedstuffs. Their toxicity has caused severe health and economic problems worldwide [1]. Among this group of mycotoxins, aflatoxin B1 has been found to be one of most potent naturally occurring carcinogens and is most frequently found in foods and feeds. The toxicity of aflatoxin B1 varies considerably with the amount of toxin, species, age and sex of animal exposed to it. The extent of exposure, health and nutritional status of the host are also important factors as there is no safe level for aflatoxins [2]. The degree of humidity, temperature and accustomed methods of storage of our food commodities bring good media for fungi to develop and produce their toxic metabolites [3].

Acute aflatoxicosis is dramatically characterized by severe clinical disease and death. Outbreaks of aflatoxicosis among human, animals and birds have been documented [2]. Consumption of grains containing aflatoxin B1 impairs liver and kidney functions, delays blood clotting, interferes with cellular and humoral immune systems and affects the reproduction indirectly by reducing feed intake and growth $[4,5]$. Chronic infection with aflatoxin B1 is one of the major determinants for hepatocellular carcinoma [6]. Even if levels of aflatoxin B1 are below those necessary to elicit recognizable clinical disease, reduction in growth rate occurs. This is attributed to aflatoxin B1 dependant reduction of the quality of feed in term of both energy and protein value resulting in monetary loss to the animal industry [4]. Human exposure to aflatoxin B1 can be from direct consumption of contaminated commodities or from food derived from animals previously exposed to this toxin in their feed [1]. 
Therefore, multiple approaches are needed to improve detection of aflatoxin B1 for minimizing the economic impact of this toxin on the entire agriculture industry and their harmfulness to human and animal health. In recent years, there has been a growing awareness of the use of immunological based technique to identify aflatoxin B1. Initial research involved the development of specific polyclonal antibodies to aflatoxin B1 and their application in techniques such as enzyme linked immuno-sorbent assay and radio-immune assay [7]. More recently, monoclonal antibodies have been developed and used for detection of aflatoxins. This technology offers a long-term supply of more specific and sensitive antibodies $[8,9]$. The aim of this work was planned to prepare monoclonal antibodies against aflatoxin B1 and characterization of these monoclonal antibodies in terms of isotyping and specificity.

\section{Materials and Methods}

\section{Preparation of the immunogen:}

Since aflatoxin B1 has no reactive group for coupling reaction, it was first converted to aflatoxin B1-O-carboxymethyl oxime using the method described by Wilkinson et al. [10]. Preparation of aflatoxin B1-bovine serum albumin conjugates [11]: Three $\mathrm{mg}$ of aflatoxin B1-O-carboxymethyl oxime were dissolved in $10 \mathrm{ml}$ of $25 \%$ ethanol - water. Five $\mathrm{mg}$ of bovine serum albumin (BSA) in $0.5 \mathrm{ml}$ of distilled water was added to aflatoxin B1-oxime solution containing $188 \mathrm{mg}$ of 1-ethyl 3(3-dimethyl aminopropyl) carbodiimide (EDPC). The reaction mixture was stirred at room temperature, in complete darkness, for 48 hours. Two additional $376 \mathrm{mg}$ portion of EDPC were added to the reaction mixture during this period. After reaction, the mixture was dialyzed against three litres of distilled water and changed daily for five days. The final solution was passed through a membrane filter (Millipore Corp.) and kept frozen before being used for immunization.

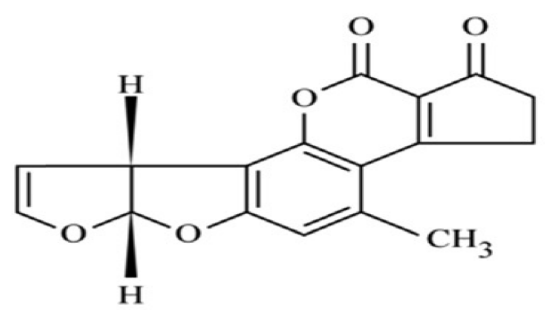

Figure 1. Chemical structure of aflatoxins B1 (AFB1).

Preparation of monoclonal antibodies against aflatoxin B1:

\section{Immunization protocol:}

After preparation of a stable emulsion of aflatoxin B1-bovine serum albumin conjugate in Freund's adjuvant, Immunization schedule for production of immune spleen cells was performed according to $[12,13]$ : A total of 10 six weeks old female Balb/c mice were immunized. Each mouse was injected with six successive doses of aflatoxin B1-bovine serum albumin conjugate according to the immunization protocol shown in Table 1. After the last immunization dose and before the fusion, blood samples were collected from the retro-orbital plexus of the immunized mice [14] and the collected serum samples were examined for anti-aflatoxin B1 antibody titer using ELISA to evaluate the humoral immune response of the immunized mice. The tested serum samples were classified as positive if their ELISA absorbance values exceed the mean value of the negative control samples by more than two standard deviations [15].

$$
\text { Cut off value }=X+2 S D
$$

where $\mathrm{X}=$ the mean value of the negative control samples, $\mathrm{SD}=$ the standard deviation.

Anti-aflatoxin B1 antibody titers were determined, compared and strong responders were selected for fusion experiment. 
The animal experiments had followed the National Institutes of Health guide for the care and use of Laboratory Animals (NIH Publications No. 8023, revised 1978).

Table 1. Immunization protocol.

\begin{tabular}{|c|c|c|c|c|}
\hline Dose No. & Adjuvant & Time & Route & Volume \\
\hline First dose & CFA & Zero time & $\mathrm{I} / \mathrm{P}$ & $0.5 \mathrm{ml}$ \\
\hline Second dose & IFA & $\begin{array}{c}\text { After 2 weeks } \\
\text { from first dose }\end{array}$ & $\mathrm{I} / \mathrm{P}$ & $0.5 \mathrm{ml}$ \\
\hline Third dose & IFA & $\begin{array}{c}\text { After 4 weeks } \\
\text { from first dose }\end{array}$ & $\mathrm{I} / \mathrm{P}$ & $0.5 \mathrm{ml}$ \\
\hline $\begin{array}{c}\text { Final doses } \\
4^{\text {th }} \text { dose } \\
5^{\text {th }} \text { dose } \\
6^{\text {th }} \text { dose }\end{array}$ & & $\begin{array}{c}\text { 4days before fusion } \\
\text { 3 days before fusion } \\
\text { 2 days before fusion }\end{array}$ & $\begin{array}{l}\mathrm{I} / \mathrm{P} \\
\mathrm{I} / \mathrm{P}\end{array}$ & $0.5 \mathrm{ml}$ \\
\hline
\end{tabular}

$C F A=$ Complete Freund's adjuvant, IFA = Incomplete Freund's adjuvant, I/P = Intraperitoneal.

Preparation of myeloma cells [13,16]: Myeloma cells were cultured two weeks before the fusion and adapted to grow in RPMI-1640 medium supplemented with $20 \%$ fetal calf serum in $5 \% \mathrm{CO} 2$, $37^{\circ} \mathrm{C}$ temperature and $98 \%$ relative humidity incubator, at density between $10^{7}-10^{8}$ cells $/ \mathrm{ml}$. Before each splitting of cells, myeloma cells were counted to follow their growth and viability. At the day before fusion, the highly viable cultures were selected and divided into a suitable number of culture vessels to be in the log phase at the fusion time (viability should be $95 \%$ or more).

No. of cells $/ \mathrm{ml}$ suspension $=$ No. of cells counted in $0.1 \mathrm{~mm}$ area $\mathrm{X} 10^{4} \mathrm{X}$ dilution factor.

\section{Storage of cells (Freezing and recovery of cell lines):}

\section{* Freezing [17]:}

For cell storage, cell density of $2-10 \times 10^{6}$ cells in $0.25 \mathrm{ml}$ freezing medium per cryo tube was used. Cells were resuspended and counted. Cells were centrifuged at $1000 \mathrm{rpm}$ for 5 minutes. Appropriate volume of cold freezing medium was added to the cell pellets. Cell pellets were resuspended and aliquot of $0.25 \mathrm{ml} /$ cryo tube was dispensed. The cryo tubes were placed in the polystyrene box and placed in $-80^{\circ} \mathrm{C}$ freezer immediately and were transferred to a liquid nitrogen tank within 24 hours for long term storage.

\section{* Thawing [17]:}

The cells in the cryo tube were thawed as quickly as possible in $56^{\circ} \mathrm{C}$ water bath. The cells were diluted gradually with $20 \mathrm{ml}$ cold serum free medium (RPMI-1640 medium with gentamycin sulfate). The cells were centrifuged at $1000 \mathrm{rpm}$ for 5 minutes. Cell pellet was resuspended in growth medium and transferred to 24 well tissue culture plates and the cells were inspected after setting.

\section{Fusion procedure:}

* The fusion technique was performed according to the basic protocol developed by [18] with some modifications according to [19].

\section{Preparation of myeloma cells:}

The previously prepared culture vessels of myeloma cells were knocked gently several times to resuspend cells in their own media. The cells were collected in $50 \mathrm{ml}$ capacity sterile conical centrifuge tubes and pelleted at $1000 \mathrm{rpm}$ for 5 minutes at $4^{\circ} \mathrm{C}$. The supernatant fluid was aspirated and the cells were resuspended in $10 \mathrm{ml}$ RPMI serum free medium. Another cycle of centrifugation and resuspension of cells was performed for a complete elimination of serum remnants. The cells were counted using haemocytometer and the cell number was adjusted to $0.5-1 \mathrm{X} 10^{7}$ cell/ $\mathrm{ml}$ of serum free medium. The cells were kept in the $\mathrm{CO}_{2}$ incubator with frequent tilting till preparation of spleen cells. 


\section{Preparation of mouse spleenocytes:}

The selected hyper-immunized mouse was anesthetized by inhalation of ACE in a closed beaker, and then slaughtered for collection of as much blood as a source of the positive mouse polyclonal antiserum. The mouse was immersed in $70 \%$ ethyl alcohol for surface sterilization and fixed on a dissecting board from its fore and hind limbs with pins. Under the laminar air flow, the abdominal skin was opened longitudinally with a set of scissors and forceps followed by blunt dissection and fixation of the skin to the board with another pins. Using another set of scissors and forceps, the abdominal muscles and the peritoneal wall were opened carefully and fixed also to the dissecting board. The spleen was then removed aseptically and washed three times in serum free medium by moving it from Petri dishes to another. In a new sterile Petri dish containing $10 \mathrm{ml}$ serum free medium, the spleen was transferred and a hole was made at one side of the spleen using a sterile toothed forceps. A plastic syringe of $5 \mathrm{ml}$ capacity was filled with serum free medium from the Petri dish and the syringe needle was inserted in the other end of the spleen. The syringe content of medium was pushed out gently to force spleenocytes to get out from the spleen. This process was repeated several times to obtain as much as possible of spleen cells. The serum free medium containing spleen cells was collected in $15 \mathrm{ml}$ tube and cells were pelleted at $1000 \mathrm{rpm}$ for 5 minutes at $4^{\circ} \mathrm{C}$. The supernatant medium was gently aspirated and the cell pellet was resuspended in pre warmed hypotonic lysis buffer with pipetting up and down several times. Five $\mathrm{ml}$ serum free medium were then added to the tube followed by centrifugation at $1000 \mathrm{rpm}$ for 5 minutes at $4^{\circ} \mathrm{C}$. The cells were washed one more time with serum free medium, resuspended in $2 \mathrm{ml}$ serum free medium and counted using the haemocytometer.

\section{Fusing both myeloma and spleen cells:}

The prepared myeloma cells were mixed with the mouse spleenocytes in $50 \mathrm{ml}$ centrifuge tube in a ratio of 1:5, respectively. Mixed cells were pelleted at $1000 \mathrm{rpm}$ for 5 minutes at $4^{\circ} \mathrm{C}$. The supernatant fluid was completely and carefully aspirated with a plugged Pasteur pipette. One $\mathrm{ml}$ of polyethylene glycol (PEG) 50\% solution was added directly on the cell pellet drop by drop in a period of one minute. Ten $\mathrm{ml}$ serum free medium (SFM) were then added over the PEG within 4 minutes in the following volume/ time strategy: $1 \mathrm{ml} \mathrm{SFM} \mathrm{in} 1$ minute, $1 \mathrm{ml}$ SFM in 1 minute, $4 \mathrm{ml}$ SFM in 1 minute and 4ml SFM in 1 minute.

The newly fused cells were subsequently centrifuged at $1000 \mathrm{rpm}$ for 5 minutes at $4^{\circ} \mathrm{C}$ and cell pellet was resuspended in a suitable volume of complete HAT medium supplied with $20 \%$ fetal calf serum (about $20 \mathrm{ml}$ ). Fused cells were transferred to a Petri dish containing the remaining volume of HAT selective medium. The total used volume of HAT selective medium was $100 \mathrm{ml}$. With wide mouthed tips, the medium contains the fused cells were distributed in all the wells of five 96 well tissue culture plates $\left(200 \mathrm{ul} /\right.$ well). The plates were then incubated at $37^{\circ} \mathrm{C}$ and $5 \% \mathrm{Co}_{2}$ tension. Nothing was done with the plates until the fifth day post fusion.

\section{Feeding hybridomas (post fusion care of cells):}

Five days after plating out the cells in HAT medium, all the wells of each plate received an additional volume (about $100 \mathrm{ul}$ ) of complete HAT selective medium. At the $7^{\text {th }}$ day post fusion, 100 ul of the HAT medium was aspirated from each well and replaced with an equal volume of fresh complete HT medium. The same process was repeated day after day (i.e.: at the days no. 9, 11, 13, $15,17 \ldots . .$. etc. post fusion). From the $10^{\text {th }}$ day after fusion, the plates were continuously observed under the inverted microscope to follow the growth of hybridomas and determine the suitable time for screening hybridomas.

\section{Screening using ELISA:}

The procedure of screening using ELISA was conducted as described by [20]: Wells that contain colonies of hybridoma covering $30 \%$ or greater of the well surface were marked. $100 \mathrm{ul}$ of the hybridoma supernatant were aspirated from each marked well and transferred to another clean 96 well microtiter plate in an organized manner. After removing samples for screening, fresh HT medium was added to the hybridomas. Also, determining of mouse monoclonal antibody isotyping was done using ELISA. 


\section{Expansion of positive antibodies secreting wells:}

One $\mathrm{ml}$ complete HT medium was added to each $2 \mathrm{ml}$ well of tissue culture plate ( 24 wells). Positive antibodies secreting hybridomas were suspended in the medium. $100 \mathrm{ul}$ from each well was transferred to $2 \mathrm{ml}$ well of 24 wells tissue culture plate and mixed well. $100 \mathrm{ul}$ of this hybridoma mixture was returned to the original well. After 2 days, hybridomas were fed with an additional 0.5 $\mathrm{ml}$ of complete HT medium. Two days later, much supernatant was removed as possible and one $\mathrm{ml}$ fresh complete HT medium was added to each well. When hybridomas were nearly confluent (up to about 1 week), they were transferred to $25 \mathrm{ml}\left(75 \mathrm{Cm}^{3}\right)$ tissue culture flasks.

\section{Freezing and recovery of hybridomas:}

Freezing cells: Freezing of positive reacting hybridomas after screening was performed as described by [21]. Several days before freezing, the desired hybridoma cell line was grown in suitable number of culture vessels till it reached a density of approximately $1-2 \times 10^{5}$ cells/ $1 \mathrm{ml}$ (cells should be healthy and rapidly dividing to be frozen). The tissue culture vessel was agitated vigorously for detachment of cells from the surfaces. The cell suspension was transferred to one or more $15 \mathrm{ml}$ sterile centrifuge tubes. The cells were pelleted at $1000 \mathrm{rpm}$ for 5 minutes at $4^{\mathrm{O}} \mathrm{C}$. The supernatant was removed and cells were resuspended in freezing medium to obtain a cell density of $1-2 \times 10^{6}$ cells/ 1 $\mathrm{ml} .0 .5 \mathrm{ml}$ of cell suspension was placed in each cryo tube. The cryo tubes were subsequently marked and enclosed with paraffin film, then transferred to a deep freezer of $-80^{\circ} \mathrm{C}$ and kept in it overnight. In the next day, the cryo tubes were placed in a polystyrene tube rack and immersed in the liquid nitrogen tank.

Recovery of frozen cells: Frozen cells were recovered a few days after freezing for insurance of the efficiency of freezing. The frozen cryo tube was removed from the liquid nitrogen tank carefully. As soon as possible, the content of the cryo tube was thawed completely in a $37^{\circ} \mathrm{C}$ water bath. The top of the cryo tube was wiped with alcohol swab and cells were transferred to a $15 \mathrm{ml}$ centrifuge tube containing $10 \mathrm{ml}$ complete culture medium. The cell suspension was then centrifuged at $1000 \mathrm{rpm}$ for 5 minutes at $4^{\circ} \mathrm{C}$ and cell pellet was resuspended in another $10 \mathrm{ml}$ complete HT medium. Cells were subsequently transferred to a tissue culture flask where it was incubated overnight at $37^{\circ} \mathrm{C}$. The viability of the recovered cells was followed up daily till cells look healthy and were dividing well.

\section{Results}

Monitoring of immunization of Balb/c mice: Three mice were selected from the immunized group because of their good response, as the measured antibody titer using ELISA was $\leq 1 / 1600$.

\section{Microscopical examination of the fusion plates:}

Results of microscopical examination of fusion plates 12 days post fusion. Living wells: number of wells that contain hybridoma with $30 \%$ or greater growth, selected for the first screening after fusion as shown in Table 2 .

Table 2. Results of microscopical examination of fusion plates 12 days post fusion.

\begin{tabular}{|c|c|c|c|c|c|}
\hline \multirow{2}{*}{ No. of plate } & \multirow{2}{*}{ No. of used wells } & \multicolumn{2}{|c|}{ Living wells } & \multicolumn{2}{c|}{ Dead wells } \\
\cline { 3 - 6 } & & No. & $\%$ & No. & $\%$ \\
\hline $\mathbf{1}$ & $\mathbf{9 6}$ & $\mathbf{1 6}$ & $\mathbf{1 7}$ & $\mathbf{8 0}$ & $\mathbf{8 3}$ \\
\hline $\mathbf{2}$ & $\mathbf{9 6}$ & $\mathbf{2 0}$ & $\mathbf{2 1}$ & $\mathbf{7 6}$ & $\mathbf{7 9}$ \\
\hline $\mathbf{3}$ & $\mathbf{9 6}$ & $\mathbf{2 0}$ & $\mathbf{2 1}$ & $\mathbf{7 6}$ & $\mathbf{7 9}$ \\
\hline $\mathbf{4}$ & $\mathbf{9 6}$ & $\mathbf{1 4}$ & $\mathbf{1 4 . 5}$ & $\mathbf{8 2}$ & $\mathbf{8 5 . 5}$ \\
\hline $\mathbf{5}$ & $\mathbf{9 6}$ & 85 & 16 & $\mathbf{8 1}$ & $\mathbf{8 4}$ \\
\hline Total & 480 & 18 & 395 & 82 \\
\hline
\end{tabular}

Living wells: number of wells that contain hybridoma with $30 \%$ or greater growth, selected for the first screening after fusion. 


\section{Results of screening of supernatants from wells showing $30 \%$ or greater hybrid cell growth for monoclonal antibodies to aflatoxin B1 using ELISA:}

The screening of aflatoxin B1 specific monoclonal antibodies production was made 12 days post fusion on supernatants from the hybrid cell growth that covers $30 \%$ or greater of the surface area of the wells. ELISA test was done using plates coated with aflatoxin B1-bovine serum albumin conjugate and with bovine serum albumin alone in order to detect monoclonal antibodies against aflatoxin B1. As shown in Tables 3\&4 and Fig. 2, the results revealed that out of 85 hybridomas selected, 20 hybridomas were reactive to aflatoxin B1-bovine serum albumin conjugate and not to bovine serum albumin and one hybridoma was reactive to both of them. Three hybridomas were highly reactive to aflatoxin $\mathrm{B} 1$.

Table 3. Results of screening of the fusion plates for production of monoclonal antibodies against aflatoxin B1 using ELISA 12 days post fusion.

\begin{tabular}{|c|c|c|c|c|c|}
\hline \multirow{2}{*}{ No. of plate } & \multirow{2}{*}{ No. of used wells } & \multicolumn{2}{|c|}{ Positive wells } & \multicolumn{2}{l|}{ Negative wells } \\
\cline { 2 - 6 } & & No. & $\%$ & No. & $\%$ \\
\hline 1 & 96 & 4 & 4 & 92 & 96 \\
\hline 2 & 96 & 5 & 5 & 91 & 95 \\
\hline 3 & 96 & 4 & 4 & 92 & 96 \\
\hline 4 & 96 & 3 & 3 & 93 & 97 \\
\hline 5 & 96 & 5 & 5 & 91 & 95 \\
\hline Total & 480 & 21 & 4 & 459 & 96 \\
\hline
\end{tabular}

Table 4. Collective summary of the ELISA results of screening of hybridoma positive wells for monoclonal antibodies production specific to aflatoxin B1.

\begin{tabular}{|c|c|c|c|c|}
\hline \multirow{2}{*}{$\begin{array}{c}\text { Fusion } \\
\text { plate No. }\end{array}$} & \multirow{2}{*}{$\begin{array}{c}\text { No. of } \\
\text { positive } \\
\text { wells }\end{array}$} & \multicolumn{3}{|c|}{ Location of positive wells } \\
\cline { 3 - 5 } & 4 & High positive & Medium positive & Low positive \\
\hline 1 & 5 & $1 \mathrm{~A} 4$ & $1 \mathrm{G} 12$ & $1 \mathrm{E} 4$ \& $1 \mathrm{G} 7$ \\
\hline 2 & 4 & $2 \mathrm{G} 8$ & $2 \mathrm{C} 1$ & $2 \mathrm{D} 11,2 \mathrm{G} 7 \& 2 \mathrm{H} 9$ \\
\hline 3 & 3 & -- & $3 \mathrm{D} 4,3 \mathrm{E} 2 \& 3 \mathrm{E} 7$ & $3 \mathrm{C} 9$ \\
\hline 4 & 5 & $4 \mathrm{E} 8$ & -- & $4 \mathrm{C} 2 \& 4 \mathrm{C} 7$ \\
\hline 5 & 21 & -- & $5 \mathrm{D} 2,5 \mathrm{G} 7 \& 5 \mathrm{H} 9$ & $5 \mathrm{~A} 3 \& 5 \mathrm{~A} 9$ \\
\hline Total & & & \\
\hline
\end{tabular}

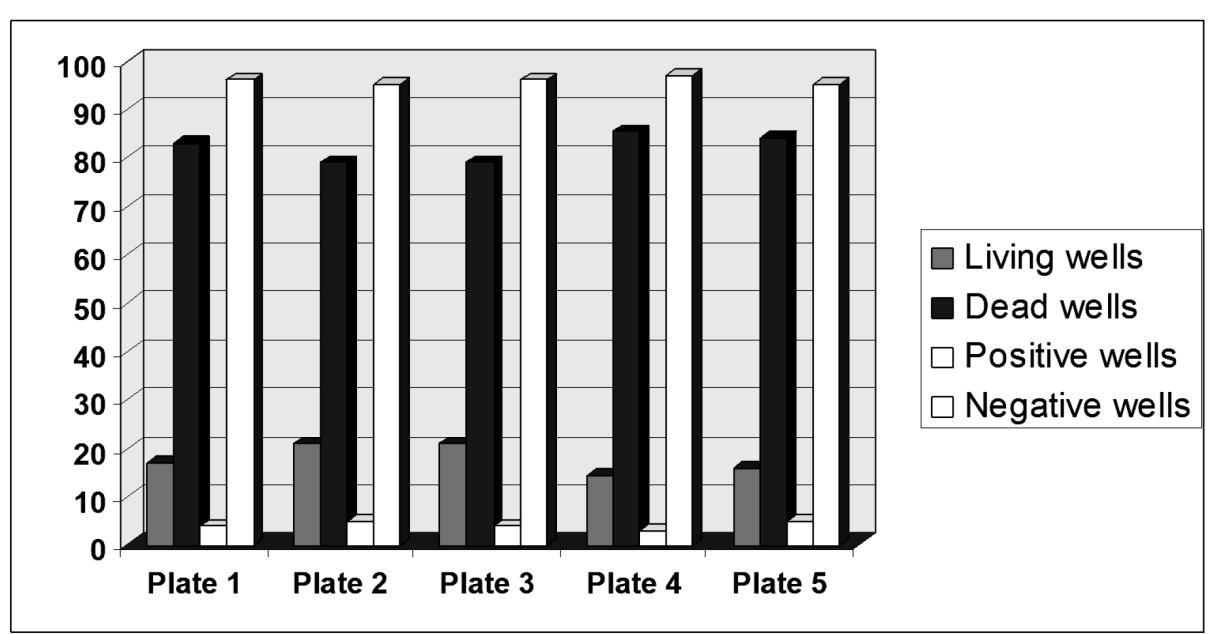

Figure 2. Correlation between microscopical examination and ELISA screening test in 5 fusion plates 12 days post fusion. 


\section{Characterization of the monoclonal antibodies produced by the highly producer hybridomas:}

Using ELISA and immunoglobulin isotyping kits, isotyping of monoclonal antibodies produced by nine hybridomas was determined. Eight hybridomas were found to belong to $\operatorname{IgG}_{2 a}$ isotype and one hybridoma was found to belong to IgM isotype (Table 5).

Table 5. Summarized the results of characterization of the monoclonal antibodies produced by the highly producer hybridomas.

\begin{tabular}{|c|c|c|}
\hline $\begin{array}{c}\text { Anti-mouse } \\
\text { specific antibody type }\end{array}$ & $\begin{array}{c}\text { Hybridoma } \\
\text { encoded name }\end{array}$ & No. of hybridomas \\
\hline $\operatorname{Ig~G2a}$ & 1A4, 4E8, 2G8, 1G12 & 8 \\
\hline Ig M & 2C1,3D4, 3E2 \& 5H6 & 1 \\
\hline
\end{tabular}

\section{Discussion}

Aflatoxins are a group of toxic metabolites produced by Aspergillus flavus and Aspergillus parasiticus. Among this group of toxins, aflatoxin B1 was found to be one of the most potent environmental carcinogens. The biological and toxicological properties of aflatoxin B1 and the impact of this series of mycotoxins on human and animal health have been well documented [22, 23]. Acute aflatoxicosis was dramatically characterized by severe clinical disease and death. Outbreaks of aflatoxicosis among human, animals and birds have been reported by [2]. The pathological lesions associated with acute aflatoxicosis include hepatocellular necrosis [24], immunosuppressive [25] and alteration of renal function [26], all of which are potentially lethal. Chronic exposure typically results in reduced performance, hepatic neoplasia and increased susceptibility to a wide variety of infections [27]. The immunosuppression is mediated at least in part by reduced phagocytic capability, decreased expression of CD14 on macrophages and reduced nitric oxide production [28]. Human exposure to aflatoxin B1 can be from direct consumption of contaminated commodities or from food derived from animals previously exposed to this toxin in their feed [1]. Liver cancer has been related to dietary intake of aflatoxins. The most recent epidemiological studies tend to indicate that individuals who are carriers of persistent viral infection with hepatitis B virus and who are exposed to aflatoxin B1 in their diets are at increased risk for progression to liver cancer as compared with hepatitis B virus carriers who are not exposed to aflatoxin B1 [29]. Aflatoxin B1 also act as immunosuppressents which may be in association with an increased prevalence of repeated infections that found among the inhabitants of buildings with moisture problems [30].

In this scope and considering the health hazards, in various countries have put action levels for aflatoxin B1 on imported food. The levels set for Figures range from 1-10 ppb aflatoxin B1 [31]. In most developing countries limited or no facilities for monitoring these toxins in foods or feeds. They are based on physicochemical methods such as thin layer chromatography (TLC) and to a limited extent high-performance liquid chromatography (HPLC). These methods are laborious and require expensive instrumentation and clean up of the samples. Immunological methods which are cost effective and adaptable to the situation in developing countries have been reported for the estimation of aflatoxins using polyclonal antibodies [32]. However, commercial kits using immunological methods are expensive, and in many countries can be problematic to import.

Aflatoxins are low molecular weight, toxic fungal metabolites and thus are devoid of antigenicity. The toxins also lack a reactive group for the coupling of the toxin to a macromolecule carrier for antibody production. However, through derivation, a free carboxylic group is introduced to the toxin molecule, thus permitting the molecule to react covalently with protein as concluded by Chu and Ueno [11].

Wilkinson et al. [10] showed that 13 mol of aflatoxin B1-oxime were successfully coupled to 1 mol of bovine serum albumin (BSA). This ratio was used in this investigation to produce an immunogen. 
Although polyclonal antibodies have been used with success for therapeutic and prophylactic purposes from infectious diseases, monoclonal antibodies (MAbs) discovered by Kohler and Milstein in 1975 [33] starting to replace the polyclonal antisera production offering substantial advantages in terms of specificity, potency, reproducibility and freedom from contaminants [34]. On the other hand, the monoclonal antibodies market has experienced and explosive growth in the last 30 years and more than 15 monoclonal antibodies have been approved for therapeutic purposes and several hundred are approved for diagnostic approach making this technology one of the fastest growing fields of biotechnology and biopharmaceutical industry and it is estimated that this technology will represent more than $40 \%$ of the total biopharmaceutical industry [9].

The present work was planned to produce monoclonal antibodies against aflatoxin B1 as a preliminary step toward the preparation of monoclonal diagnostic product for aflatoxin B1. Primary immunization of Balb/c mice was performed by intra-peritoneal injection of aflatoxin B1-BSA conjugate mixed with complete Freund's adjuvant. At two weeks intervals from the primary immunization, two booster doses of the immunogen mixed with incomplete Freund's adjuvant were injected intra-peritoneal in the Balb/c mice. The Freund's adjuvant was used to induce sustained immune response against aflatoxin B1-BSA conjugate. The last booster doses were given in a form of purified aflatoxin B1-BSA conjugate 4, 3 and 2 days before fusion. This immunization protocol was similar with that applied by Wang et al. [6].

Immunization procedure, however, differs from that applied by Candlish et al. [35] who used four intra-peritoneal injections at weekly intervals and by Ward et al. [36] who used four intraperitoneal injections at monthly intervals with a final immunization 3 days prior to fusion. In contrast, Devi et al. [37] gave boosters 18 days before fusion because booster injections given 3 days before fusion resulted in the selection of only a few monoclonal antibodies.

To monitor the progress of immunization procedure, an enzyme linked immuno-sorbent assay (ELISA) screening test was used for declaration of the immunization level and selection of well responder (immunized) Balb/c mice. Three mice were selected from the immunized group because of their good response as the measured antibody titer was $\leq 1 / 1600$. ELISA is nearly the master screening technique used in monoclonal antibody technology because of its rapidity and the easiness with which the test can be done with several hundred of samples [38]. Also, Farzad and James [39] reported that ELISA is a rapid and sensitive immuno-assay for the quantitation of anti-aflatoxin B1 antibodies.

In the present work, we used hybridoma supportive mixture and OPI supplement which support the growth of the hybridoma. Although, other researchers supplemented the tissue culture plates with feeder cells (i.e., peritoneal macrophage, thymocytes) before fusion procedure that secrete growth factors which stimulate the growth of the hybridomas, remove toxic by-product from media and exert a synergistic effect. Also, they increase markedly the yield of the hybrids and remove the dead parental cells and debris from the cultures [40].

In concern with the fusion procedure, the spleenocytes (B cells) harvested from a hyperimmunized Balb/c mice were fused with myeloma cell lines (P3 NS1). The myeloma cells were selected in $\log$ phase with viability over $95 \%$. The fusion between B cells and myeloma cells was supported by the fusogenic polyethylene glycol (PEG) 3000, 50\% concentration. PEG is a poly wax material that promotes cell adherence and exchange of their nuclei. PEG induces the formation of somatic cell hybrids and facilitated an improved and simplified technique for cell fusion in vitro [41].

Normally cell fusion can occur spontaneously in culture at low levels but its incidence can be increased by treatment of cells with a fusigenic agent like polyethylene glycol (PEG) [42]. This agent still is widely used in fusion technology by most laboratories at a concentration of $40-50 \%(\mathrm{w} / \mathrm{v})$. Schidegger and Groth [43] and Davis et al. [12] reported that fusion can be performed with several types of polyethylene glycol (PEG) (1000-4000 MW) at concentration of 45-50\% and gave the best results. 
Several factors contributed in the success of the fusion between mouse spleenocytes and myeloma cells, in addition to the type of fusigenic agent used in the fusion experiment. In the present study we utilize a suitable type of myeloma cells which characterized by non-secretory type of cells (not secrete heavy and light chain) and the viable and stable appearance. Successive subculture of the myeloma cells revealed its stability and viability when incubated under our laboratory conditions.

The fusion technology using the different ratio between myeloma cells and spleenocytes have been tried by several authors. In the present work 1:5 cell ratio between myeloma cells and spleenocytes has been used. This differs from what was done by Kenimer James and William[44] who fused $\left(10^{8}\right)$ spleen cells and $\left(10^{7}\right)$ myeloma cells in fusion process in the presence of $50 \%$ polyethylene glycol (PEG) 3000 solution added to the mixture of both cells. On the other hand, Sheppard Anthony and Cusell [45] fused $\left(2 \times 10^{8}\right)$ immunized rat spleen cells with $\left(10^{8}\right)$ rat myeloma cells with good fusion results.

The produced spleen myeloma cells hybridomas were selected from the unfused cells and undesirable fused cells, using hypoxanthine aminopterin thymidine (HAT selective medium) according to Little and Gall [46]. Exposure of fusion cultures to a selective medium with hypoxanthine, aminopterin and thymidine reduced the labor involved and increased the yield. Cell fusion is random; therefore, the cell culture contains a mixture of myeloma-spleen cells fusion, myeloma-myeloma cells fusion and spleen-spleen cells fusion. Selection of myeloma-spleen cells fusion can be only accomplished by culturing the cell mixture in hypoxanthine aminopterin thymidine (HAT) medium. Plasmacytoma cell line is deficient in enzyme hypoxanthine guanine phosphoribosyl transferrase (HGPRT) responsible for incorporation of hypoxanthine. Post-fusion care starting five days after plating out the cells in HAT medium with addition of $100 \mathrm{ul}$ of complete HAT selective medium for each well. At $7^{\text {th }}$ day post fusion, replacement of $100 \mathrm{ul}$ of the medium with fresh medium containing hypoxanthine-thymidine (HT) instead of hypoxanthine-aminopterin-thymidine (HAT) occurred. At this time, small hybridoma growth was detected at the margin of several wells.

As shown in Table 2, 12 days post fusion, 85 hybridoma cell growth that covering $30 \%$ or greater of the surface area of the wells was screened for antibody production against aflatoxin B1bovine serum albumin conjugate and bovine serum albumin alone using ELISA technique. In the present work, we succeeded to recover 20 positive hybridomas, as shown in Tables (3), found to be reactive to aflatoxin $\mathrm{B} 1$-bovine serum albumin conjugate and not to bovine serum albumin and one clone was reactive to both of them. Three clones were highly reactive to aflatoxin B1. Positive hybridoma producing specific monoclonal antibodies against aflatoxin B1 namely (1A4, 1E4, 1G7, 1G12, 2G8, 2C1, 2D11, 2G7, 2H9, 3E7, 3D4, 3C9, 3E2, 4E8, 4C2, 4C7, 5D2, 5G7, 5H6, 5A3 \& 5A9). These hybridoma cell lines were expanded and freezed by immersing in the liquid nitrogen tank for further work.

\section{Conclusions}

In the present work (Table 5); the nine hybridoma clones namely (1A4, 4E8, 2G8, 1G12, 2C1, 3D4, 3E2, 5H6 \& 3E7) had been isotyped. Eight clones were found to belong to IgG2a isotype and one clone (3E7) was found to belong to IgM isotype using enzyme linked immuno-sorbent assay procedure and mouse immunoglobulin isotyping kits. Also, Kenimer James and William [44] and Volk and Bizzini [47] assayed the clones' supernatant of their immunoglobulin class and subclass specificity by ELISA.

Today, the industry is working as furiously as ever to perfect the design and production of monoclonal antibodies (MAbs) for the therapeutic purposes. Similarly, we aim by the present work to begin the preliminary step required for production of antibodies against aflatoxin B1 using monoclonal antibody technology. We are sure that more intensive and hard work is required to reach to this phase but at least the (21) obtained hybridoma cell lines will be further intensively cloned, characterized and reevaluated for the achievement of our main goal. 


\section{References}

[1] D.L. Park, Surveillance programmes for managing risks from naturally occuring toxicants, Food Addit. Contam. 12(3) (1995) 361-371.

[2] D. Bhatnagar, J. Yu, K.C. Erlich, Toxins of filamentous fungi, Chem. Immunol. 81 (2002) 167206.

[3] V. Vujanovic, W. Smoragiewicz, K. Krzysztyniak, Airborne fungal ecological niche determination as one of the possi-bilities for indirect mycotoxin risk assessment in indoor air, Environ Toxicol. 16(1) (2001) 1-8.

[4] M.A. Diekman, M.L. Green, Mycotoxins and reproduction in domestic livestock, J. Anim. Sci. 70(5) (1992) 1615-1627.

[5] F. Temamogullari, A. Kanici, Short communication: Aflatoxin M1 in dairy products sold in S, anliurfa, Turkey. J Dairy Sci. 97 (2014) 162e5.

[6] J.S. Wang et al., Development of aflatoxin B (1)-lysine adduct monoclonal antibody for human exposure studies, App. Environ. Microbiol. 67(6) (2001) 2712-2717.

[7] F.S. Chu, Immunochemical studies on mycotoxins, in: H. Kurata, Y. Ueno (Eds.), Toxigenic Fungi, Tokyo, Kodansha 1td, 1984, pp. 234-244.

[8] S. Deng, Y. Xu, R. Liu, Mimic epitope of aflatoxin B1 screened by phage display techniquae, Wei. Sheng Yan Jiu. 36(1) (2007) 59-62.

[9] D. Zhang et al., Production of ultrasensitive generic monoclonal antibodies against major aflatoxins using a modified two-step screening procedure, Anal Chim Acta. 639 (2009) 63e9.

[10] J. Wilkinson et al., Immune response to a mucosally administered aflatoxin B1 vaccine. Poult. Sci. 82 (2003) 1565-1572.

[11] Chu, F.S. and Ueno, I. Production of antibody against aflatoxin B1, Appl. Environ. Microbiol. 1977. 33 (5): 1125-1128.

[12] W.C. Davis, T.C. Mcguire, C. Travis, Biomedical and biological application of monoclonal antibody technology in developing countries, Periodicum Biologorum. 85(3) (1983) 259-282.

[13] F.M. Ausubel, R. Brent, Current protocols in molecular biology, John Wiley \& Sons, New York, 2003.

[14] Wiggenhauser, A. Jacking blood from mice. Monoclonal antibodies, Peters J.H. and Baumgarten, H. Springer-Verlag Berlin Heidelberg, New York, 1992.

[15] Gast, R.K.; Porter, E.R. and Holt, P.S. Applying tests for specific yolk antibodies to predict contamination by Salmonela enteritidis. Poult. Sci., 1997. 70: 1273-1276.

[16] Ali, M. Monoclonal antibodies production against breast cancer. PH. D thesis, Military Medical Academy, 2001.

[17] Harlow, E. and Lane, D. Antibodies, A laboratory manual. Cold spring laboratory, USA, 1988.

[18] Gefter, M.L.; Margulies, D.L. and Schraff, M.D. A simple method for polyethylene glycol promoted hybridization of mouse myeloma cells. Somatic Cell Genetics, 1977. 3: 231-236

[19] Amer, H.M. Productio and characterization of monoclonal antibodies to Avian Reo Virus. M.V.Sc., Fac. of Vet. Medicine, Cairo University, 2001.

[20] D.B. Synder et al., Rapid serological profiling by enzyme linked immunosorbent assay. III simultaneous measurements of antibody titer to Infectious bronchitis, Infectious bursal disease and NewCastle disease virus in a serum dilution. Avian Diseases, 1984. 28: 12-24.

[21] Zola, H. Monoclonal antibodies. The basis- Edited by: BIOS Publishers, 2000. 
[22] Wogan, G. Mycotoxins. Annu. Rev. Pharmacol., 1975. 15: 437-451.

[23] Anukul N, Vangnai K, Mahakarnchanakul W. Significance of regulation limits in mycotoxins contamination in Asia and risk management programs at the national level. J Food Drug Anal., 2013. 21:227e41.

[24] Bryden, W.L. and Cumming, R.B. Observaton on the liver of the chickens following aflatoxin B1 ingestion. Avian Pathol., 1980. 9: 551-556.

[25] J.S. Virdi et al., Effects of aflatoxin on the immune system of the chick. J. Appl. Toxicol., 1989 9: 271-275.

[26] Glahn, R.P. Mycotoxins and the avian kidney: assessment of physiological function. World's Poult. Sci. J., 1993. 49: 242-250.

[27] R.I. Brown et al., Resistance to aflatoxin accumulation in kernels of maize inbred selected for ear rot resistance in west and central Africa. J. Food Prot., 2001. 64: 396-400.

[28] Moon, E.Y. and Pyo, S. Aflatoxin B1 inhibits CD14-mediated nitric oxide production in murine peritoneal macrophages. Int. J. Immunopharmacol., 2000. 22: 237-246.

[29] H.C. Wu et al., Aflatoxin $B_{1}$ Exposure, Hepatitis B Virus Infection and Hepatocellular Carcinoma in Taiwan. Cancer Epidemiol.Biomarkers Prev., 2009. 18(3): 846-853.

[30] Reijula, K. and Tuomi, T. Mycotoxins of Aspergilli: Exposure and health effects. Front Biosci., 2003. 1 (8): 232-235.

[31] Ozay, G. and Alperden, I. Aflatoxin and ochratoxin A contamination of dried figs (Ficus Carinal) from the 1988 crop. Mycotox. Res., 1991. 7: 85-97.

[32] Zhang, G. and Chu, F.S. Production and characterization of antibodies cross reactive with major aflatoxins. Experientia, 1989. 45 (2): 182-184.

[33] Kohler and Milstein. Continuous cultures of fused cells secreting antibody of predefined specificity. Nature, 1975. 256: 495-497.

[34] Hay Frank, C. and Westwood Olwyn, M.R. Practical immunology-Monoclonal antibodies: Production, purification and enzymatic fragmentation. PP.: 40-70. $4^{\text {th }}$ edition, Black well science, 2002.

[35] Candlish, A.A.; Stimson, W.H. and Smith, J.E. A monoclonal antibody to aflatoxin B1: Detection of the mycotoxin by enzyme immunoassay. Lett. Appl. Microbiol., 1985. 1: 57-61.

[36] Ward, C.M.; Wilkinson, A.P.; Bramham, S.; Lee, H.A.; Chan, H.W.; Butcher, G.W.; Hutchings, H. and Morghan, M.R.A. Production and characterization of polyclonal and monoclonal antibodies against aflatoxin B1 oxime-BSA in an enzyme linked immunosorbent assay. Mycotox. Res., 1990. 6: 73-83.

[37] Devi, K.T.; Mayo, M.A.; Reddy, K.L.; Delfosse, P.; Reddy, G.; Reddy, S.V. and Reddy, D.V. Production and characterization of monoclonal antibodies for aflatoxin B1. Lett. Appl. Microbiol., 1999. 29: 284-288.

[38] Kane, M. and Banks, J.N. Raising antibodies.Cited from immunoassays. A practical approach. Edited by J. Gosling, Department of biochemistry and national diagnostic center, National Univeristy of Ireland galls way (Oxford Univeristy), 2000. PP.: 19-58.

[39] Farzad, Z. and James, K. Measurement of human and mouse anti-tetanus antibodies and isotype analysis by ELISA. J. of Immunol. Methods, 1986. 87 (1): 119-125.

[40] Quinlan and Kennedy. Enhanced cloning efficiencies of murine hybridomas using human plasma supplemented medium. J. Immunol. Methods, 1994. 123: 157-165. 
[41] Davidsen, R. and Land Gerald, P.S. Improved techniques for the induction of mammalian cell hybridization by PEG. Somatic Cell Genetics, 1976. 2 (2): 165-176.

[42] Zola, H. and Holbrook, F.L. Tolerization as a tool for generation novel monoclonal antibodies. Immunol. Cell Biol., 2002. 80 (4): 319-322.

[43] Schidegger, D. and DE Groth, S.F. Production of monoclonal antibodies: Strategy and tactics. J. Immunol. Methods, 1980. 35 (1-2): 1-21.

[44] Kenimer James, G. and William, H. Monoclonal antibodies as probes of Tetanus toxin structure and function. Infection and Immunity, 1983. 42 (3): 942-948.

[45] J. Sheppard Anthony, D. Cusell, Production and characterization of monoclonal antibodies to tetanus toxin, Infect. Immunity. 43(2) (1983) 710-714.

[46] M. Little, F.L. Gall, Of mice and men: Hybridoma and recombinant antibodies, Immunol. Today. 21(8) (2000) 355-412.

[47] W.A. Volk, B. Bizzini, Neutralization of tetanus toxin by distinct monoclonal antibodies binding to multiple epitopes on the toxin molecule, Infection and Immunity, 1984, pp. 604-609. 